\title{
IDENTIFIKASI SUMBER RISIKO PRODUKSI BROKOLI DI GAPOKTAN LEMBANG AGRI, DESA CIKIDANG, KECAMATAN LEMBANG, KABUPATEN BANDUNG BARAT
}

\author{
IDENTIFICATION OF RISK SOURCES FOR BROCOLLI PRODUCTION IN \\ GAPOKTAN LEMBANG AGRI, CIKIDANG VILLAGE, LEMBANG DISTRICT, \\ BANDUNG BARAT REGENCY
}

\author{
Ade Ramnah, Nur Syamsiyah, Agriani Hermita Sadeli, Lucyana Trimo \\ Program Studi Agribisnis, Fakultas Pertanian, Universitas Padjadjaran \\ Jln. Raya Bandung-Sumedang Km. 21, Jatinangor, Kabupaten Sumedang, Jawa Barat \\ *Email: aderamnah02@gmail.com \\ (Diterima 29-07-2021; Disetujui 15-12-2021)
}

\begin{abstract}
ABSTRAK
Subsektor hortikultura merupakan subsektor pertanian yang memiliki peran penting dalam pertumbuhan Produk Domestik Bruto (PDB) dan memiliki potensi yang sangat besar untuk dikembangkan di negara Indonesia. Brokoli merupakan salah satu sayuran yang memiliki produktivitas yang sangat pesat dikarenakan permintaan pasar yang meningkat. Gapoktan Lembang Agri merupakan Gabungan Kelompok Tani yang mengusahakan tanaman sayuran brokoli pada setiap kegiatannya. akan tetapi, produktivitas brokoli pada Gapoktan lembang Agri mengalami fluktuasi yang menghambat Gapoktan untuk memenuhi permintaan pasar. Tujuan penelitian ini adalah mengidentifikasi sumber risiko produksi brokoli di Gapoktan lembang Agri. Analisis data pada penelitian ini menggunakan metode deskriptif-kualitatif. Hasil penelitian mengidentifikasi penyebab sumber risiko produksi brokoli di gapoktan lembang agri sebanyak 22 sumber risiko.
\end{abstract}

Kata kunci: Brokoli, Risiko Produksi

\section{ABSTRACT}

The horticulture sub-sector is an agricultural sub-sector that has an important role in the growth of Gross Domestic Product (GDP) and has enormous potential to be developed in Indonesia. Broccoli is one of the vegetables that has very rapid productivity due to increasing market demand. Gapoktan Lembang Agri is an association of farmer groups that cultivate broccoli vegetables in every activity. however, the productivity of broccoli in Lembang Agri's Gapoktan has fluctuated which hinders the Gapoktan from meeting market demand. The purpose of this study was to identify sources of risk for broccoli production in Gapoktan Lembang Agri. Data analysis in this study used descriptive-qualitative method. The results of the study identified the causes of risk sources for broccoli production in Gapoktan Lembang Agri as many as 22 risk sources.

Keywords: Broccoli, Production Risk

\section{PENDAHULUAN}

Kontribusi yang di sumbangkan

oleh subsektor hortikultura terhadap

PDB, mengalami peningkatan terhadap

nilai ekspor setiap tahunnya. Secara keseluruhan kinerja ekspor buah, sayur, dan bunga-bungaan di Indonesia pada tahun 2018 cukup menggembirakan dengan kenaikan 12\%, dengan nominal nilai Rp.5 triliun lebih. Ekspor sayur naik 


\section{IDENTIFIKASI SUMBER RISIKO PRODUKSI BROKOLI DI GAPOKTAN LEMBANG AGRI, \\ DESA CIKIDANG, KECAMATAN LEMBANG, KABUPATEN BANDUNG BARAT \\ Ade Ramnah, Nur Syamsiyah, Agriani Hermita Sadeli, Lucyana Trimo}

$4,8 \%$, bunga $7 \%$, dan buah-buahan 26,3\%. Menurut Direktorat Jendral Hortikultura Kementrian Pertanian (Kementan 2019).

Pada tahun 2018, tingkat konsumsi masyarakat Indonesi sebesar 54,0 $\mathrm{kg} / \mathrm{kap} /$ tahun, sedangkan untuk konsumsi buah sebesar $36,5 \mathrm{~kg} / \mathrm{kap} / \mathrm{tahun}$, dengan kata lain bahwasannya masyarakat Indonesia lebih banyak mengkonsumsi sayuran daripada buah-buahan. Pola konsumsi sayur yang berubah akibat pengetahuan akan gizi yang dapat di peroleh dengan mengkonsumsi sayur, serta tingkat kesejahteraan masyarakat, dapat membuka peluang permintaan sayur (Kementan, 2019). Menurut Kementrian Pertanian, standar konsumsi sayuran yang direkomendasikan oleh Food and Agricultural Organization (FAO) adalah 65,75 kilogram perkapita pertahun, sedangkan tingkat konsumsi sayuran pada tahun 2017 51,7 kilogran perkapita pertahun. Mengidikasikan bahwa prospek pengembangan sayur di Indonesia sangat tinggi, didukung dengan karakteristik wilayahnya yang subur.

Berdasarkan hasil survei Badan Pusat Statistika (2014) Provinsi Jawa Barat merupakan pemasok sayuran terbesar di Indonesia dengan presentase 23\%, dilanjut dengan Provinsi Jawa
Tengah dengan presentase $20 \%$, dan Provinsi Jawa Timur sebesar 14\%. Kesesuaian agroklimat dengan rata-rata curah hujan lebih dari $2000 \mathrm{~mm}$ per tahunnya, dan rata-rata bulan basah 8-10 bulan dan agroekosistem, sehingga kawasan ini sesuai untuk produksi dan pertumbuhan sayuran dataran tinggi tersebut (Dinas Pertanian Jawa Barat, 2016).

Menurut BPTP (2021) Salah satu komoditas sayuran yang memiliki nilai ekonomi tinggi adalah brokoli. Tanaman brokoli mudah dibudidayakan baik secara konvensional maupun modern dan memberikan keuntungan yang cukup tinggi. Potensi pengembangan komoditas brokoli secara ekonomi dapat meningkatkan pendapatan petani, pengentasan kemiskinan, perbaikan gizi, perluasan kesempatan kerja, penguranan impor, dan peningkatan ekspor nonmigas.

Salah satu Gabungan Kelompok Tani yang mengembangkan komoditas sayuran brokoli adalah Gabungan Kelompok Tani Lembang Agri yang berlokasi di Kecamatan Lembang, Kabupaten Bandung Barat. Menurut Hasil wawancara bersama ketua Gapoktan Lembang Agri, 2020 "Sayuran Brokoli merupakan salah satu sayuran 
yang menjadi penyumbang terbesar pendapatan di Gapoktan Lembang Agri”

Akan tetapi produktivitas dari sayuran brokoli tidak stabil, hal ini disebabkan oleh gangguan hama penyakit, faktor cuaca yang tidak menentu yang mengakibatkan penurunan kualitas dan kuantitas, dan juga kurangnya tenaga kerja yang memadai, permodalan hingga kurangnya fasilitas yang ada. Ketidak stabilan produksi brokoli dapat mengakibatkan tidak terpenuhinya permintaan pasar, pada saat permintaan pasar tidak dapat terpenuhi maka ketua Gapoktan Lembang Agri mengaku sering kewalahan sehingga mereka harus mencari sayuran brokoli pada kelompok tani atau Gapoktan lainnya supaya dapat memenuhi permintaan pasar.

Oleh karena itu, Gapoktan Lembang Agri memerlukan strategi mitigasi risiko produksi dengan menggunakan pendekatan diagram tulang ikan yang digunakan untuk membantu pengidentifikasian akar dari penyebab suatu permasalahan, membantu menyelidiki atau mencari fakta lebih lanjut.

\section{MOTODE PENELITIAN}

Teknik penelitian yang digunakan adalah studi kasus. Tempat penelitian di Gapoktan lembang Agri, Desa Cikidang, Kecamatan Lembang, Kabupaten Bandung Barat. Data terdiri dari data sekunder dan data primer. Pengumpulan data primer dilakukan dengan cara observasi dan wawancara secara mendalam kepada 65 orang petani anggota Gapoktan Lembang Agri yang telah melakukan teknis budidaya brokoli.

\section{Diagram Fishbone}

Diagram tulang ikan merupakan salah satu metode untuk meningkatkan kualitas, yang dikemukakan oleh seorang ilmuwan asal jepang yaitu Dr. Kaouru Ishikawa pada tahun 60 -an.

Suatu tindakan akan mudah dilakukan apabila masalah dan akar penyebab masalah telah ditemukan. Manfaat diagram tulang ikan adalah dapat menolong kita untuk menemukan akar penyebab masalah secara user friendly yang disukai oleh orang-orang manufaktur dimana proses disana mempunyai ragam variabel yang berpotensi menyebabkan munculnya permasalahan (Purba, 2008). 
1. Menggambar garis horizontal dengan tanda panah pada ujung sebelah kanan dan gambar kotak didepan anak panah yang berisi masalah yang diteliti.

Masalah

\section{Gambar 1. Menentukan Masalah Utama}

2. Tuliskan penyebab utama dalam kotak yang dihubungkan kearah garis panah utama.

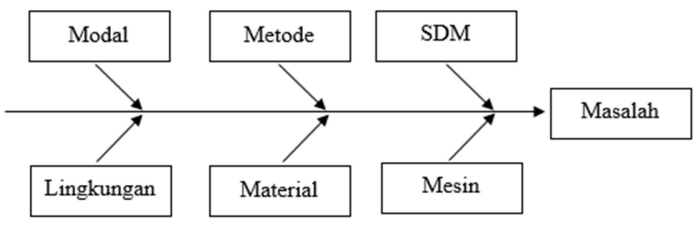

Gambar 2. Menentukan Penyebab Utama

3. Tuliskan penyebab kecil disekitar penyebab utama dan hubungkan tanda panah dengan penyebab utama.

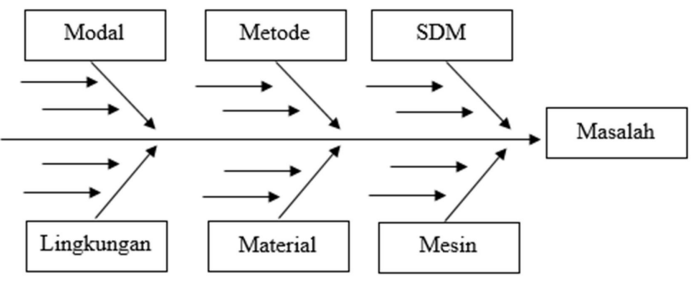

Gambar 3. Menentukan Masalah Lainnya

4. Menentukan sebab-sebab potensial dan menentukan penyebab yang paling dominan dari permasalahan yang terjadi.

5. Menentukan tindakan perbaikan untuk pemecahan permasalahan yang ada di kelompok tani Gapoktan Lembang Agri dengan cara wawancara dengan menggunakan teknik FMEA dan diskusi dengan informan.

\section{HASIL DAN PEMBAHASAN}

Gapoktan Lembang Agri terdiri atas 9 kelompok tani, yang memiliki kepengurusan tiap kelompoknya, dan memiliki lahan pribadi petani yang cukup luas untuk diusahakan.

Tabel 4. Daftar anggota Gapoktan Lembang Agri

\begin{tabular}{clcc}
\hline No. & $\begin{array}{c}\text { Kelompok } \\
\text { Tani }\end{array}$ & $\begin{array}{c}\text { Jumlah } \\
\text { Anggota } \\
\text { (Orang) }\end{array}$ & $\begin{array}{c}\text { Luas } \\
\text { Areal } \\
\text { Tanah } \\
\text { (Ha) }\end{array}$ \\
\hline 1. & Tauhiid & 37 & 30 \\
2. & Saluyu & 25 & 10 \\
3. & Berkah Tani & 30 & 15 \\
4. & Mulya Tani & 23 & 10 \\
5. & Alam Tani & 10 & 10 \\
6. & Kawani Asih & 20 & 5 \\
7. & Sangkuriang & 15 & 8 \\
8. & Sundang & 15 & 7 \\
9. & Putra Lembang & 10 & 5 \\
\hline & Jumlah & $\mathbf{1 8 5}$ & $\mathbf{1 0 0}$ \\
\hline
\end{tabular}

$$
\text { Brokoli yang dijual oleh }
$$

Gapoktan Lembang Agri akan di salurkan pada pasar modern dan juga pasar tradisional. Brokoli dikemas menggunakan plastic wrap dan diberi stiker brand produk untuk disalurkan pada pasar modern, sedangkan penyaluran pada pasar tradisional dikemas perbal dengan berat rata-rata sesuai dengan pesanan konsumen. 
Identifikasi penyebab risiko

Identifikasi risiko dilakukan

berdasarkan risiko produksi yang terjadi

pada setiap tahapan produksi di Gapoktan

Lembang Agri. Proses identifikasi

diketahui melalui proses wawancara kepada informan yang paling mengetahui teknis budidaya brokoli di Gapoktan Lembang Agri, yaitu Bapak Dodih selaku ketua Gapoktan Lembang Agri, Bapak selaku sekertaris, dan Ketua Kelompok tani.

Tabel 5. Risiko Produksi dan Penyebab Risiko Produksi Brokoli di Gapoktan Lembang Agri

\begin{tabular}{|c|c|c|}
\hline $\begin{array}{l}\text { Keragaan } \\
\text { Usahatani } \\
\end{array}$ & Risiko yang akan terjadi & Risiko yang akan terjadi \\
\hline Persiapan lahan & $\begin{array}{l}\text { Berkurangnya jumalah organisme } \\
\text { yang bermanfaat }\end{array}$ & \\
\hline $\begin{array}{l}\text { Persiapan rumah } \\
\text { lindung untuk bibit }\end{array}$ & Terjadinya hujan angin kencang & $\begin{array}{l}\text { Rumah lindung yang tidak sesuai dengan } \\
\text { SOP }\end{array}$ \\
\hline $\begin{array}{l}\text { Penyiapan net } \\
\text { tanaman }\end{array}$ & $\begin{array}{l}\text { Keterbatasan modal untuk } \\
\text { penyediaan net }\end{array}$ & $\begin{array}{l}\text { Kurangnya petani dalam perkiraan tumbuh } \\
\text { tanaman }\end{array}$ \\
\hline $\begin{array}{l}\text { Penyiapan benih, } \\
\text { pupuk, pestisida }\end{array}$ & - & Tidak terencananya pengadaan bahan baku \\
\hline pembibitan & $\begin{array}{l}\text { Cuaca yang kurang sesuai untuk } \\
\text { pertumbuhan dan perkembangan } \\
\text { tanaman }\end{array}$ & $\begin{array}{l}\text { Kekurangan bibit dengan varietas yang } \\
\text { sesuai }\end{array}$ \\
\hline penanaman & Kesalahan jarak tanam & - \\
\hline pengairan & - & $\begin{array}{l}\text { Ketidak sesuaian jumlah air yang } \\
\text { dibutuhkan tanaman }\end{array}$ \\
\hline $\begin{array}{c}\text { Pemberian zat } \\
\text { pengatur tumbuh }\end{array}$ & - & $\begin{array}{l}\text { Ketidak sesuaian dosis zat pengatur } \\
\text { tumbuh }\end{array}$ \\
\hline penyulaman & $\begin{array}{l}\text { Tidak tersedianya bibit untuk } \\
\text { kegiatan penyulaman }\end{array}$ & $\begin{array}{l}\text { Kelalaian petani dalam melakukan } \\
\text { penyulaman terhadap tanaman yang mati }\end{array}$ \\
\hline penyiangan & - & $\begin{array}{l}\text { Kelalaian petani dalam melakukan } \\
\text { penyiangan }\end{array}$ \\
\hline pemupukan & Waktu pemupukan yang tidak sesuai & Ketidak sesuaian dosis pemberian pupuk \\
\hline Pemangkasan & - & $\begin{array}{l}\text { Kurangnya pengetahuan petani dalam } \\
\text { melakukan pemangkasan bunga brokoli }\end{array}$ \\
\hline $\begin{array}{l}\text { Perlindungan } \\
\text { tanaman }\end{array}$ & $\begin{array}{l}\text { Kondisi tanaman yang kurang bersih } \\
\text { dan sehat, kurangnya kebersihan diri } \\
\text { petani, kelalaian petani dalam } \\
\text { mengendalikan hama dan penyakit }\end{array}$ & $\begin{array}{l}\text { Ketidak sesuaian dosis pestisidaa, } \\
\text { serangan hama penyakit, kurangnya respon } \\
\text { petani dalam menjaga kebersihan perlatan }\end{array}$ \\
\hline Panen & Waktu panen yang tidak sesuai & Keslahan memotong batang brokoli \\
\hline
\end{tabular}

Berdasarkan diagram fishbone atau diagram sebab akibat, diatas bagian kepala merupakan malasah utama yang di hadapi oleh Gapoktan Lembang Agri, diamana risiko ini akan di cari tau penyebab utama risiko terjadi. Bagian tulang ikan yang berbentuk garis diagonal berisikan penyebab masalah yang dapat berpengaruh terhadap risiko utama. Garis kecil yang terdapat pada garis diagonal 


\section{IDENTIFIKASI SUMBER RISIKO PRODUKSI BROKOLI DI GAPOKTAN LEMBANG AGRI, \\ DESA CIKIDANG, KECAMATAN LEMBANG, KABUPATEN BANDUNG BARAT \\ Ade Ramnah, Nur Syamsiyah, Agriani Hermita Sadeli, Lucyana Trimo}

merupakan sub-penyebab risiko. Sumber risiko yang terjadi di Gapoktan Lembang Agri di identifikasi secara internal dan eksternal. Faktor internal yang dimaksudkan yaitu manusia, metode, manajemen, dan material. Sedangkan, faktor eksternal yaitu lingkungan sekitar produksi Gapoktan Lembang Agri.

\section{Manusia}

Kendala yang terjadi di Gapoktan Lembang Agri yang diakibatkan manusia adalah kelalaian para petani dalam mengendalikan hama penyakit, kelalaian petani dalam penyulaman tanaman yang mati, kelalaian petani dalam melakukan penyiangan, kurangnya pengetahuan petani dalam perkiraan tumbuh tanaman brokoli, dan kelalaian petani dalam menjaga kebersihan peralatan.

2. Metode

Risiko yang di hadapi diantaranya ketidak sesuaian penggunakan pupuk, penggunaan pestisida untuk membasmi hama dan penyakit tanaman, kesalahan pada jarak tanam, kesalahan memotong batang tanaman pada saat panen sehingga brokoli tidak masuk dalam sortir, volume aira yang di buthkan belum sesuai dengan kebutuhan tanaman terkadang tanaman kelebihan air pada saat musim hujan dan kekurangan air pada saat musim kemarau walaupun terdapat sumur bor akan tetapi tidak terlalu merata.

3. Manajemen

Kurang terencana sehingga membuat pengeluaran yang besar. Waktu pemupukan yang tidak tepat, dan waktu panen yang tidak sesuai sehingga kualitas bunga brokoli yang tidak sesuai dengan spesifikasi yang diinginkan

4. Material

Keterbatasan modal dalam pengadaan net untuk melindungi bibit atau tanaman brokoli dari paparan sinar matahari yang berlebih. Tidak tersedianya bibit untuk penyulaman

\section{Lingkungan}

Cuaca yang tidak sesuai dengan pertumbuhan bunga brokoli yaitu curah hujan yang sangat tinggi akan mengakibatkan kebusukan pada bunga sehingga tanaman tidak bisa dipanen, apabila cuaca panas akan mengakibatkan kelayuan pada tanaman brokoli, sehingga tidak layak dijual. Selain cuaca, penyebab penurunan faktor produksi yaitu hama dan penyakit seperti Hama ulat tritip atau ulat daun (Plutellaxylostella), Ulat tanah (Agrotislpsilon), Kutu daun (Aphis Brassicae), Ulat jengkal (Trchoplusiana sp), Siput (Achatina fulica), Busuk hitam (Xanthomonas campestris Dows), Akar Bengkak atau Akar Pekuk 
(Plasmodiophora brassicae Wor.),

Bercak hitam (Alternaria sp.).

\section{Sumber Risiko yang Teridentifikasi}

Sumber risiko yang teridentifikasi oleh diagram fishbone, meliputi: Ketidak sesuaian dosis pestisida, Ketidak sesuaian pupuk, Waktu pemupukan yang tidak tepat, Ketidak sesuaian jumlah air, Kelalaian petani dalam mengendalikan hama dan penyakit, Kurangnya pemahaman petani dalam pemangkasan bunga brokoli, Kurangnya pemahaman petani dalam perkiraan tumbuh tanaman, Kurangnya petani dalam menjaga kebersihan peralatan, Kerusakan fasilitas budidaya, Kekurangan bibit dengan varietas yang sesuai, Kondisi tanaman yang kurang bersih, Tidak terencananya bahan baku, Serangan hama dan penyakit, Terjadinya hujan angin yang kencang, Cuaca yang kurang sesuai dengan pertumbuhan dan perkembangan tanaman, Berkurangnya jumlah organisme tanaman yang bermanfaat, Keterbatasan modal dalam penyediaan net tanaman, Kelalaian petani dalam melakukan penyulaman tanaman, Tidak tersedianya bibit untuk kegiatan peyulaman, Kelalaian petani dalam melakukan penyiangan, Waktu panen tidak sesuai, Kesalahan dalam memotong batang brokoli.

\section{KESIMPULAN DAN SARAN}

\section{Kesimpulan}

Dari hasil identifikasi dilapangan menggunakan metode diagram fishbone, teridentifikasi sebanyak 22 sumber risiko yang dapat menyebabkan kegagalan panen dan kerusakan tanaman, sehingga tidak terpenuhinya permintaan pasar dikarenakan hasil produksi yang berfuktuatif.

\section{Saran}

Berdasarkan kesimpulan yang ada, diharapkan Gapoktan Lemabang Agri untuk melakukan identifikasi secara mendalam tentang sumber risiko tersebut dan melakukan aksi mitigasi secara berkala, sehingga akan mengurangi dampak dari risiko tersebut seperti hasil produksi yang berfluktuatif dan tidak dapat memenuhi permintaan pasar.

\section{DAFTAR PUSTAKA}

Ardianto, E. 2011. Metodologi Penelitian Untuk Public Relations Kuantitatif Dan Kualitatif. Bandung: Simbiosa rekatama media.

Arikunto, S. 2013. Prosedur Penelitian: Suatu Pendekatan Praktik. Jakarta: Rineka Cipta.

BPTP. 2021. Upaya Introduksi Sayuran Bernilai Komsersial Tinggi.

Cahyono, B. 2001. Kubis Bunga dan Broccoli. Kanisius, Yogyakarta. Halaman 12-14

Creswell W. J. 2013. Research Design Pendekatan Kualitatif, Kuantitatif, 
dan Mixed. Yogyakarta : Pustaka Pelajar.

Djaelani, A. R. 2013. Teknik Pengumpulan Data dalam Penenilitian Kualitatif.

Djohanputro, B. 2008. Manajemen Risiko Korporat. Pendidikan dan Pembinaan Manajemen, Jakarta.

Forrest W, Breyfogele III. 2003. Implementing Six Sigma: Smarter Solution Using Statistical Methods. 3rd ed. John Wilwy \& Sons, Inc., New Jersey.

Hanindita, N., 2008. Analisis Eksport Tomat Segar Indonesia, Ringkasan Eksekutif, Institut Pertanian Bogor.

Hasan, F. dkk. 2018. Risiko Produksi dan Perilaku Petani Mengahadapi Risiko Usahatani Bawang Merah di Kabupaten Nganjuk. INISIASI Volume 7 No. 2. Akses 17 September 2019.

Hernanto F. 1991. Ilmu Usahatani. Jakarta: Penebar Swadaya

Kholil, M. dkk. 2013. Six Sigma Quality For Business Improvement. Jakarta: Graha Ilmu.

Leitch, R.D. 1995. Reliability Analysis for Engineering An Introduction. New York : Oxford University Press Inc.

Naftaliasari, T. dkk. 2015. Analisis Risiko Usahatani Kedelai di Kecamatan Raman Utara Kabupaten Lampung Timur. JIIA, Vol. 3, No. 2. Akses 17 September 2019.

Palladini, E. dkk. 2011. Pengelolaan Risiko Penciptaan Nilai Melalui Pendanaan Usaha Mikro. Jakarta: Salemba Empat.

Pasaribu, A. 2007. Analisis Usahatani Brokoli di Desa Cibodas Kecamatan Lembang Bandung Barat. Skripsi. Fakultas Pertanian Universitas Padjadjaran Bandung.

Purba. 2008. Diagram Fishbone Dari Ishikawa.
Ramadhan, A. 2013. Analisis Risiko Produksi Cabai Paprika di Kelompok Tani Dewa Family Desa Pasirlangu Kecamatan Cisarua Kabupaten Bandung Barat. Akses 01 Januari 2020

Rubatzky, V. E. dan M. Yamaguchi, 1998. Sayuran Dunia 2 Prinsip, Produksi, dan Gizi. ITB, Bandung.

Rukmana, R. 1995. Budidaya Kubis Bunga dan Brokoli. Yogyakarta: Kanisius.

Sari, N. dkk. 2018. Analisis Risiko Usahatani Kopi Specialty Java Preanger. Researchgate. Akses 17 September 2019.

and Bioeconomy. Akses

Shinta, N. D. dkk. 2017. Analisis Risiko Produksi Baby Buncis pada Kelompok Tani di Kabupaten Bandung Barat. JISPO Vol. 7, No. 2. Akses 21 Juni 2019.

Soeharjo, A dan Patong. 1973. SendiSendi Pokok Usahatani. Jurusan Ilmu Sosial Ekonomi Pertanian. Institut Pertanian Bogor: Bogor.

Soekartawi, dkk. 1986. Ilmu Usahatani dan Penelitian untuk Pengembangan Petani Kecil. Universitas Indonesia Press. Jakarta.

Sugiyono. 2016. Metode Penelitian Kuantitatif, Kualitatif dan $R \& D$. Bandung: PT Alfabet.

Sugiyono. 2017. Metode Penelitian Kuantitatif, Kualitatif, dan $R \& D$. Bandung: Alfabeta, CV

Syamsiah, N. dkk. 2019. Identifikasi Risiko Usahatani Mangga Dalam Pengembangan Agrowisata di Kabupaten Cirebon. Sosiohumaniora vol. 21, No. 1. Akses 17 September 2019.

Tague, N. 2005. The Quality Toolbox. United States of America: ASQ. 